\title{
The Potential of Prophecy: Māori Prophetism and Community Development
}

In nineteenth century Aotearoa-New Zealand prophetleaders challenged the hegemony of colonialism by melding Indigenous ideas with introduced ideas, as a means of both cultural survival and resistance against colonialism. One such nineteenth century prophet-leader was Te Kooti Arikirangi Te Turuki (c.1832-c.1891) who blended traditional Māori knowledge with biblical ideas. Te Kooti gave many prophecies delivered as riddles rich with metaphor and mystery. Following severe land loss in the Rangitaiki Valley in the Bay of Plenty of New Zealand at the hands of a white man, Te Kooti issued a prophecy of promise and restoration. Within the Māori tribes of Patuheuheu and Ngāti Haka, to whom this prophecy was given, Te Kooti's revelations of hope gained new meaning; his words continually transported from history into the present.

This paper will begin by giving some historical background around the emergence of the prophecy. This paper will also demonstrate the potential of prophecy by showing how Te Kooti's prophecy has been used as the basis for a research model which I have developed for my doctoral thesis. My doctoral research aims to use Te Kooti's prophecy as a platform on which to build a tribally relevant community development framework for the future.

Māori connections to land are pivotal to Māori identity. However, the Government of New Zealand disrupted these connections by claiming a pre-emptive right to land which was considered 'unused'. The basis for this claim was New 
Zealand's founding document, the Treaty of Waitangi, signed in 1840 (Cheater \& Hopa, 1997; Orange, 1987; Walker, 1990). The State launched an assault on Māori who refused to sell their land and by 1900 the relatively new State had acquired over ninety per cent of the country as State-owned assets and land earmarked for the plethora of Pākehā or white settlers (Cheater \& Hopa, 1997; Walker, 1990). The Government became a forceful and exploitive land purchaser using methods which caused intense division within Māori society; from the late $1840 \mathrm{~s}$, secret land purchasing deals were facilitated by Government officials without thorough investigations into land ownership (Ballara, 1996). Huge lots of land were also confiscated by the Government as a method of punishment for Māori resistance, whilst also servicing the insatiable settler appetite for land (Boast \& Hill, 2009; Gilling, 2009).

In the 1870s, the Patuheuheu and Ngāti Haka tribes were considered by the Government to be rebels because they followed the nineteenth century prophet Te Kooti (Binney, 2001a, 2002, 2003; Paul, 1995; Pouwhare, 2004). Consequently they were captured and forced to relocate to an area outside of their tribal boundaries (Binney, 2001a, 2002, 2003; Paul, 1995; Pouwhare, 2004) where they were detained in what has been referred to by the late New Zealand historian Judith Binney (2002, 2003, 2009) as a 'concentration camp'. In 1872 Patuheuheu and Ngāti Haka were released and they returned to the Rangitaiki Valley where they re-established their lives at a place called Te Houhi (Arapere, 2002; Binney, 2001a, 2002, 2003, 2009; Paul, 1995). From the mid-1880s however, the lives of Patuheuheu and Ngāti Haka were to change dramatically.

In 1886 a prominent Pākehā (white man) by the name of Harry Burt, who worked as a Native Land Court interpreter, and lived in the Te Houhi community, defrauded Patuheuheu and Ngāti Haka out of legal ownership of 7,000 acres of land at Te Houhi. He did this using the Native Land Court system, 
set up by the colonists (Binney, 1997, 2001, 2002, 2009; Boast, 2008), which was an effective instrument for alienating Māori from their land (Ka'ai-Mahuta, 2010). Binney (2001a) contends that Burt belonged to a "'sub-culture': a visible group of early settled Pakeha men who lived with Maori women" (p. 162) and spoke the native language. Burt "claimed friendship and more - kinship - with Maori... He was a manipulator, who created a mood and experience of confidence and trust. $\mathrm{He}$ was a swindler who outmanoeuvred a prophet" (Binney, 2001a, p. 148) and fraudulently acquired ownership of the home base of Patuheuheu and Ngāti Haka.

When Harry Burt sold Te Houhi many court battles followed. The land eventually fell into the hands of James Grant, who has been described as 'mean spirited' (Boast, 2002). Grant made it difficult for Patuheuheu and Ngāti Haka by persecuting them and destroying their food supplies; and in the winter of 1907, assisted by the police, he evicted Patuheuheu and Ngāti Haka (Binney, 2001a, 2007; Boast, 2002; Wylie, 1908, cited in Wouden, 1980), some say at gun point. Patuheuheu and Ngāti Haka were expelled from their homes, some fled into the dense Urewera forest ranges for a time, while others relocated to Waiohau in the Eastern Bay of Plenty (Binney, 2009). Grant kept the community's school building and their wharenui or ancestral house. The government paid Grant £140 in 1908 for the wharenui which was then dismantled by Patuheuheu and Ngāti Haka and transported by horse and cart, and by river, to Waiohau where it was rebuilt and reopened in 1909 (Binney, 2001; Boast, 2002; Paul, 1995). It was the original loss of ownership of the land at Te Houhi in the mid-1880s which led to Te Kooti's utterance of a significant prophecy which offered hope for the future, in the face of devastation. 


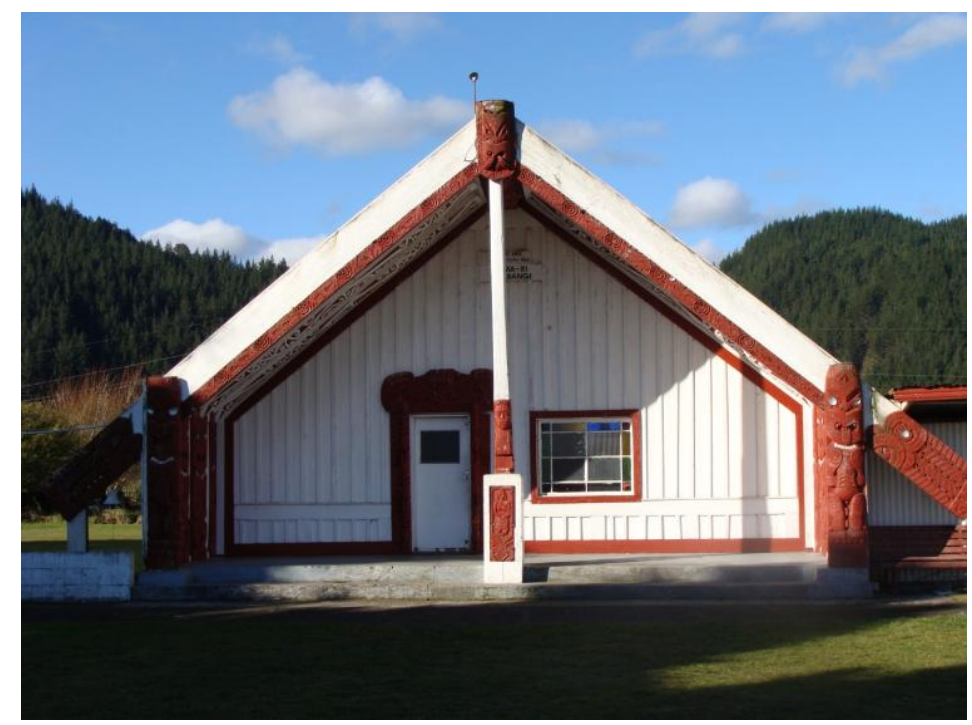

Tama-ki-Hikurangi wharenui, Waiohau. Photograph by Byron Rangiwai, 2010.

The name of Te Kooti's prophecy was Te Umutaoroa, which means 'earth oven of long cooking'. As in other parts of the Pacific, Māori in Aotearoa/New Zealand traditionally cooked food using an umu, or earth oven. A pit is dug in the earth, in which a fire is burned for a number of hours to heat stones. Once these stones are hot, food in weaved baskets is placed on top, covered in leaves, and then soil. After the required cooking time, the soil and leaves are removed and the food is ready to be served. Te Umutaoroa refers to this process of cooking in a metaphorical way, and as the name suggests, this particular umu requires a long cooking time.

Te Umutaoroa is a prophetic discourse which promised Patuheuheu and Ngāti Haka the return of their lost lands and resources, and according to some narratives, the discovery or generation of other resources such as diamonds, gold, oil and minerals (Binney, 2001a). According to one of the late leaders of Patuheuheu and Ngāti Haka, the Reverend Hieke Tupe 
(Doherty, 1995; Binney, 2001a, 2009), Te Kooti had a vision of an umu with the power to correct the wrongs of the past. It is said that Te Kooti placed eight stones, each with a particular restorative mauri or lifeforce, to be uncovered in the future (Doherty, 1995; Binney, 2001a). The mauri of Te Umutaoroa, as articulated by the late Rev. Hieke Tupe, are as follows:

te mauri atua: the essence of spirituality; the belief in God

te mauri whenua: the life force of the land te mauri tangata: the life force of the people te mauri whakapono: the power of belief, or faith

te mauri whakaora i nga iwi: the power to heal the people

te mauri hohonu: the mauri [life force] of hidden wealth - minerals, gold, diamonds and oil (perhaps), which lie underground te mauri arai atu i nga pakanga: the power to return war from this land to other countries te mauri whakahoki i nga iwi: the power to return people to their land (Binney, 2001a, p. 158).

The uncovering of these eight stones guarantees the people of Te Houhi, spiritual and physical renewal, regeneration, reuniting of people and land, and economic security (Binney, 2001a). The purpose of all umu is to cook food to feed a family, to feed a village, to feed a people, and so Te Umutaoroa promises Patuheuheu and Ngāti Haka the 'cooked sustenance' of life and salvation (Binney, 1995, 2001a, 2007, 2009).

To this day Te Umutaoroa remains unfulfilled. It is however a discourse which is in a constant state of flux shifting from the past to the present, subjected to discursive modification, shaping the prophecy for the particular contexts in which it is used to inspire and give hope. Judith Binney (2007) states that: 
Te Umutaoroa has become an unfulfilled questnarrative. It is unfulfilled because the land is lost; indeed, it is now drowned beneath the waters of a hydro-electric dam, built in 1980. Little islands dot the lake where Te Umutaoroa once was. Once again new meanings are being wrought from this changed landscape (p. 154).

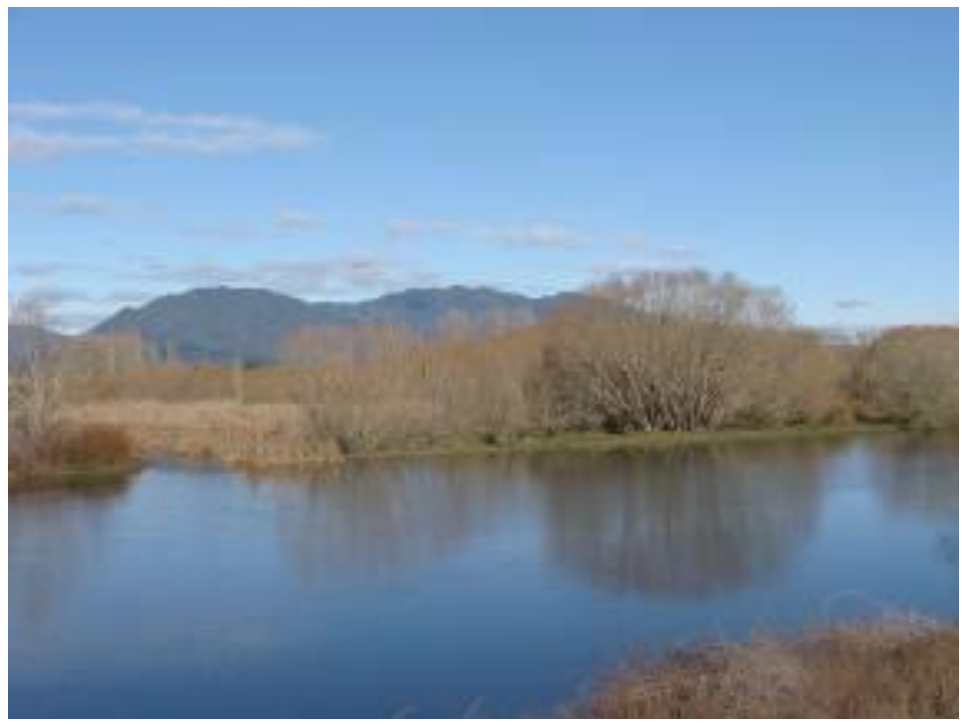

The general area where Te Kooti was said to have placed Te Umutaoroa. The area is now drowned beneath the water after the building of a hydro-electric dam in 1980. Photograph by Byron Rangiwai, 2010.

Te Kooti's prophecies were given in riddles, meaning that it is up to the individual to interpret the messages contained therein (Bennett \& Mackenzie, 2011). ${ }^{1}$ Te Umutaoroa has been subjected to interpretation throughout the generations and is still referred to today. For example, Te Umutaoroa is used to inform the pedagogy of the local Indigenous tribal school in 
Waiohau which teaches only in the Tūhoe dialect of the Māori language, and also the philosophy and practices of a Māori health, wellbeing and healing clinic. Additionally, from October 2008 the prophecy of Te Umutaoroa became the name and underpinning philosophy of a political movement. This movement included Patuheuheu and Ngāti Haka, and clan groupings from other sub-tribal areas located in the Bay of Plenty who were (and some continue to be) dissatisfied with aspects of Tūhoe tribal management.

In September 2011 Auckland based Atamira Dance Company, led by Maaka Pepene of Patuheuheu, performed an interpretive contemporary dance piece. This performance was entitled 'Te Houhi: the people and the land are one' and told the story of Patuheuheu and Ngāti Haka's land loss, whilst exploring the potential of Te Kooti's promise for the future. The work moves, according to Whyte (2011), through three stages:

Te Ao o Neheraa (the ancient world) establishes a relatively untroubled past, the Ngati Haka Patuheuheu people living in harmony and respect for the land and one another.

Te Ao Hurihuri (the world turns upside down) shows the impact of Pakeha colonisation, the rise of Te Kooti, military reactions to passive resistance, the demoralisation of the people through many years of court battles over the fraudulent sale of their land at $\mathrm{Te}$ Houhi, and finally the eviction of the people from their land, leaving behind their treasured wharenui which was inlaid with early Maori figurative art, and central to their Ringatu religion.

Te Ao Marama (the world of light) shows the eventual re-uniting of the people with their meeting house, which they dismantled and carried by hand to its new home at Waiohou [sic], along with ancestral remains and other artefacts necessary to the development of a new harmony of the people with the land. - though even today we hear on the News of ongoing tension between the Crown and Ngai Tuhoe (paras. 5-7). 
From the way in which Te Umutaoroa has been utilised, it is clear that the prophecy continues to be re-interpreted for the needs of the people. The prophecy has, according to Binney (2007) "...acquired an autonomous life. It is no longer tied [exclusively] to its origins, [and] has been transformed to possess vastly extended meanings..." (Binney, 2007, p. 154).

In my current doctoral research I am using a model which is based on interpretations of the lifeforces of Te Umutaoroa. The model centres on the lifeforce of Patuheuheu and Ngāti Haka epistemology (te mauri mātauranga o Patuheuheu me Ngāti Haka), and blends my own interpretations of the prophecy with specific research practices or outputs, some of which have been influenced by the ideas of educationalist Paulo Freire. I will now outline the eight parts of this model.

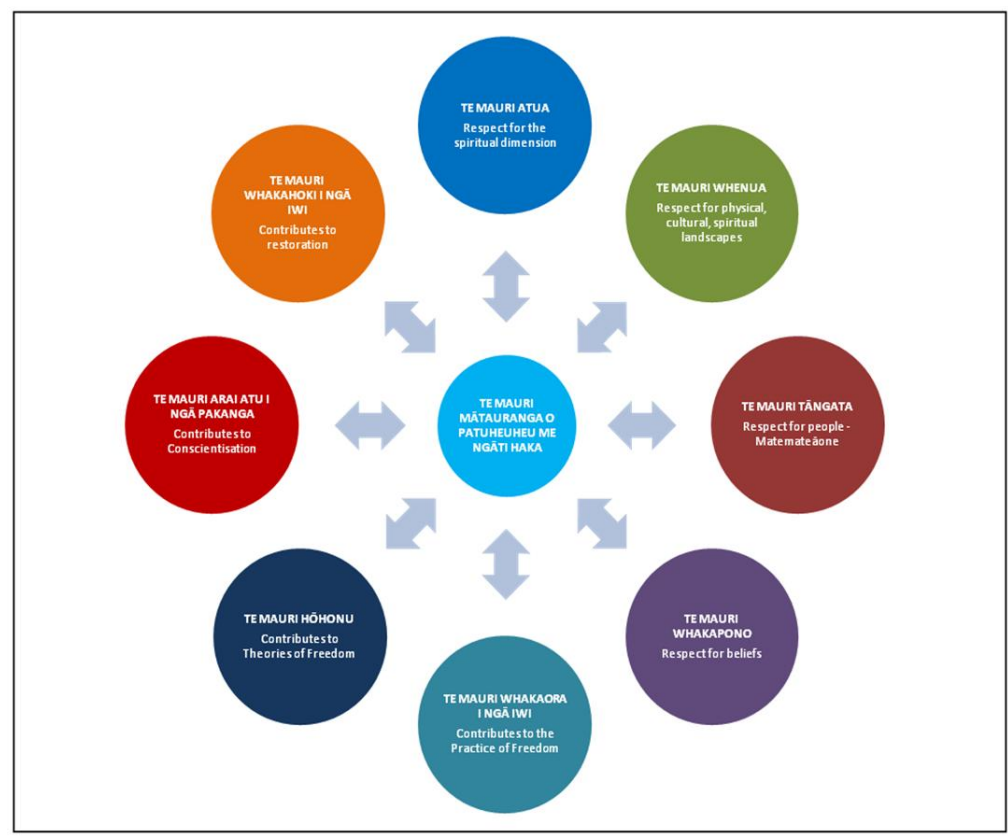

Figure 1: Te Umutaoroa Research Model 


\subsection{Te Mauri Atua: Respect for the Spiritual Dimension}

Te Mauri Atua, or the life-force of the spiritual dimension, acknowledges the connections of Patuheuheu and Ngāti Haka to the ancestors and the spiritual realm. Te Mauri Atua is about the researcher respecting the elements of the spiritual dimension with an awareness and respect for Māori cultural protocols, concepts and values.

\subsection{Te Mauri Whenua: Respect for Physical, Cultural, Spiritual Landscapes}

Te Mauri Whenua, or the life-force of the land, is about respecting the land, and in turn acknowledges the intimate interconnectivity of land, environment and people. Te Mauri Whenua insists that the researcher demonstrates respect for Patuheuheu and Ngāti Haka land, people and environment, as well as a strong familiarity with tribal history and experiences.

\subsection{Te Mauri Tāngata: Respect for People - Matemate- ä-one}

Te Mauri Tangata, or the lifeforce of the people, is about demonstrating respect, reciprocity, generosity, and matemateà-one. Matemate-ā-one refers literally to the process of dying and becoming one with the soil; this concept substantiates the interconnectedness of people and land, and describes the intense fondness and connection that exists between them (Moorfield, 2011). As a researcher therefore, it is important to demonstrate Māori cultural values in terms of showing respect to people, and ensuring that participants are taken care of. The researcher must also be aware of the absolutely cherished connections of the people to the land despite the tragedies of land loss.

\subsection{Te Mauri Whakapono: Respect for Beliefs}

Te Mauri Whakapono, or the lifeforce of hope is a principle about faith, belief and truth. Te Mauri Whakapono is the 
driving force behind Te Kooti's philosophy for change. Belief combined with action - like theory and practice - activates and transports the unlimited potentiality of being into the now, into reality. It is the power of belief which brings $\mathrm{Te}$ Umutaoroa into the lived reality of Patuheuheu and Ngāti Haka, and as such the researcher has a responsibility to show respect to the kaupapa or philosophy of Te Umutaoroa, and the differing views and ideas which surround it.

\subsection{Te Mauri Whakaora i ngā Iwi: Contributes to the 'Practice of Freedom'}

Te Mauri Whakaora i nga Iwi is about healing the people of Patuheuheu and Ngāti Haka in terms of historical injustices and breaking free from the perpetual cycle of social, political and economic oppression. Paulo Freire (1972) states: "It is absolutely essential that the oppressed participate in the revolutionary process with an increasingly critical awareness of their role as subjects of the transformation" (p. 127). Therefore the research must contribute to Patuheuheu and Ngāti Haka's engagement in the 'practice of freedom' where the oppressed liberate themselves through acting upon the world to change reality.

\subsection{Te Mauri Hōhonu: Contributes to a Theory of Freedom}

Te Mauri Hōhonu speaks of hidden or underground wealth. In terms of transformation this mauri is about deeper theoretical understandings around oppression, liberation and freedom. The hidden wealth inherent in this mauri can relate to the need for the oppressed to access new knowledge and to engage in true conscientised education: the practice of freedom. This mauri emphasises the fact that the researcher must be motivated by theories of liberation, self-determination, and transformation when working with Patuheuheu and Ngāti Haka. 


\subsection{Te Mauri arai atu i ngā Pakanga: Contributes to Conscientisation and Resistance}

Te Mauri arai atu i nga Pakanga, is about "...the power to return war from this land to other countries" (Binney, 2001a, p. 158). War can be interpreted as a metaphor for physical, symbolic and ideological conflicts with colonisation. In my view this principle is essentially about de-colonisation. It is about becoming conscientised or in other words, being conscious and aware of the nature of oppression, the political, economic and social barriers which prevent Patuheuheu and Ngāti Haka development, and how these can be overcome through praxis: action and reflection. Thus the researcher must be conscious and aware of oppression and hegemony at the global, national, and tribal levels, and must contribute to a culture of conscientisation and transformation within the community.

\subsection{Te Mauri Whakahoki i ngā Iwi: Contributes to Restoration}

Te Mauri Whakahoki i ngā Iwi is about returning the people to the land, and returning all of the lost resources. This notion has provided Patuheuheu and Ngāti Haka with the impetus to continue to resist historical and contemporary injustices, and work towards fulfilling the discourse of Te Umutaoroa: the restoration of their lost lands and resources. Therefore the researcher must engage with the community and contribute to ideas around restoration and community development.

\section{Conclusion}

The legacy of Te Umutaoroa is a potent and highly significant narrative for Patuheuheu and Ngāti Haka. Te Umutaoroa is literally a symbol of hope for a better, more just future, in the face of colonisation and severe land loss: it is a utopian vision directly connected to the history, experiences, and therefore the epistemology, of the people. Throughout its history, Te Umutaoroa has been used in a variety of contexts and in contemporary times is used to inform educational practice, 
health and healing practices, and politics. I have demonstrated my use of Te Umutaoroa to inform my model for carrying out Indigenous research within my tribes, which activates the potential of prophecy in research and in community development. This model and my research into Te Umutaoroa, will inform the future creation of a community development framework for Patuheuheu and Ngāti Haka, which I hope will be beneficial to the community in time to come.

\section{References}

Adrahtas, V. (2007). Prolegomena to the history of Indigenous Australian prophetic consciousness. Sydney Studies in Religion. Retrieved February 18, 2010 from http://escholarship.usyd.edu.au/journals/index.php/SSR/article /view/122/ 143

Andersen, J. C. (1940). Maori religion. Journal of Polynesian Society, 49, 513-555. (Andersen, J. C. (2003). Maori religion. Christchurch, New Zealand: Cadsonbury Publications).

Anderson, D. M. \& Johnson, D. H. (Eds.). (1995). Revealing prophets. Athens, $\mathrm{OH}$ : Ohio University Press.

Aranga, M. (2002). Aspects of Mätauranga Mäori: A hermeneutic exploration of whakapapa and knowledge. Unpublished master's thesis, Te Whare Wānanga o Awanuiārangi, Whakatāne, New Zealand.

Arapere, B. (2002). A history of the Waiohau blocks: a report commissioned by the Waitangi Tribunal. New Zealand: Waitangi Tribunal. (WAI 894 \#A26).

Aune, E. (1983). Prophecy in early Christianity and the ancient Mediterranean world. Grand Rapids, MI: William B. Eerdmans Publishing.

Beier, U. (2005). Decolonising the mind: The impact of the university on culture and identity in Papua New Guinea, 1971-74. Canberra, Australia: Pandanus Books.

Belich, J. (1986). The New Zealand wars. Auckland: Penguin.

Bennett, M. (Writer/Director) \& Mackenzie, K. (Director/Co-producer) (2011). Episode one. In M. Douglas (Producer), Whare Māori. Auckland, New Zealand: Māori Television Service.

Bennett, M. (Writer/Director) \& Mackenzie, K. (Director/Co-producer) (2011). Episode five. In M. Douglas (Producer), Whare Mãori. Auckland, New Zealand: Māori Television Service.

Best, E. (1923). The Maori school of learning: its objects, methods, and ceremonial. Wellington: Dominion Museum, Government Printer.

Best, E. (1924). Maori religion and mythology, part 1. Wellington, New Zealand: Te Papa Press. 
Best, E. (1925). Tuhoe: children of the mist. Auckland: Reed Publishing (NZ) Limited.

Binney, J. (1988). The Ringatu traditions of predictive history. The Journal of Pacific History, 23(2), 167-174.

Binney, J. (1997). Redemption songs: a life of Te Kooti Arikirangi Te Turuki. Auckland, New Zealand: University Press and Bridget Williams Books.

Binney, J. (2001a). Te Umutaoroa: The earth oven of long cooking. In A. Sharp \& P. McHugh (Eds.), Histories, power and loss: Uses of the past - a New Zealand commentary (pp. 146-64). Wellington, New Zealand: Bridget Williams Books Limited.

Binney, J. (2001b). Maori oral narratives, Pakeha written texts. In J. Binney (Ed.), The shaping of history - essays from the New Zealand Journal of History (pp. 2-14). Wellington: Bridget Williams Books Limited.

Binney, J. (2002). Encircled lands, part one: a history of the Urewera from European contact until 1878. An overview report on the Urewera (Wai 894 \# A15). Report to the Waitangi Tribunal, Wellington, New Zealand.

Binney, J. (2003). Statement of Judith Binney in response to questions of clarification. Wai 894. Submission to the Waitangi Tribunal, Wellington, New Zealand.

Binney, J. (2007). Te Kooti Arikirangi Te Turuki ? - 1893. In Dictionary of New Zealand Biography, updated 22 June 2007. Retrieved August 25, from http:/ / www.dnzb.govt.nz/DNZB/alt_essayBody.asp?essayID=1T4 5.

Binney, J. (2009). Encircled lands: Te Urewera, 1820-1921. Wellington: Bridget Williams Books.

Blackburn, J. (2000). Understanding Paulo Freire: Reflections on the origins, concepts, and possible pitfalls of his educational approach. Community Development Journal, 35(1), pp. 3-15.

Blaser, M., de Costa, R., McGregor, D. \& Coleman, W. D. (Eds.). (2010). Indigenous peoples and autonomy: Insights for a global age. Vancouver, BC: University of British Columbia Press.

Blenkinsopp, J. (1996). A history of prophey in Israel. London, United Kingdom: Westminster John Knox Press.

Boast, R. P. (2002). The Crown and Te Urewera in the 20th century - a study of government policy. Report to the Waitangi Tribunal, Wellington, New Zealand.

Brock, P. (Ed.). (2005). Indigenous peoples and religious change. Leiden, The Netherlands: Brill.

Cave, A. A. (2006). Prophets of the Great Spirit: Native American revitalization movements in Eastern North America. Lincoln, NE: University of Nebraska Press.

Cheater, A. \& Hopa, N. (1997). Representing identity. In A. James, J. Hockey \& A. Dawson (Eds.), After writing culture: epistemology and praxis in contemporary anthropology (pp. 208-23). Oxon: Routledge. 
Cross, F. L. \& Livingstone, E. A. (Eds.). (1997). The Oxford dictionary of the Christian Church. Oxford, United Kingdom: Oxford University Press.

Csordas, T. J. (1990). Embodiment as a paradigm for Anthropology. Ethos, 18(1), 5-47.

Doherty, W. (1995). Traditional history relating to Matahina C \& C1 \& Patuheuheu and Ngati Haka. Te Runanganui o Te Ika Whenua WAI 212.

Doherty, W. (2009). Mātauranga Tūhoe: The centrality of mātaurangaa-iwi to Māori education. Unpublished doctoral thesis, University of Auckland, Auckland, New Zealand.

Durie, M. (1998). Te mana, te kāwanatanga: The politics of Mãori selfdetermination. South Melbourne, Australia: Oxford University Press.

Elias, J. (1976). Conscientization and deschooling: Freire's and Illich's proposals for reshaping society. Philadelphia, PA: Westminster Press.

Elsmore, B. (1998). Te Kohititanga Marama: New moon, new world. Auckland, New Zealand: Reed.

Elsmore, B. (1999). Mana from heaven: A century of Maori prophets in New Zealand. Auckland, New Zealand: Reed.

Elsmore, B. (2000). Like them that dream: The Maori and the old testament. Auckland, New Zealand: Reed.

Fanon, F. (1963). The wretched of the earth (C. Farrington, Trans.). New York, NY: Grove Press.

Fanon, F. (1986). Black skin, white masks (C. L. Markmann, Trans.). London, United Kingdom: Pluto Press.

Fraser, T. N. (2009). Māori-Tūhoe epistemology: Stages of sustaining tribal identity through Tūhoe performing arts. Unpublished doctoral thesis, University of British Columbia, Vancouver, Canada.

Freire, P. (1972). Pedagogy of the oppressed. Harmondsworth, United Kingdom: Penguin.

Freire, P. (1985). The politics of education: Culture, power, and liberation (D. Macedo, Trans.). South Hadley, MA: Bergin \& Garvey.

Freire, P. (1998). Politics of education. Los Angeles, CA: UCLA Latin American Center Publications.

Freire, P. (2000). Cultural action for freedom [Monograph]. Harvard Educational Review, 1.

Freire, P. \& Macedo, D. (1987). Literacy: reading the word and the world. London: Routledge.

Geertz, A. W. (1994). The invention of prophecy: Continuity and meaning in Hopi Indian religion. Los Angeles: University of California Press.

Heertum, R. V. (2006). Marcuse, Bloch and Freire: Reinvigorating a pedagogy of hope. Policy Futures in Education, 4(1), pp. 45-51.

Hita-Brown, C. H. (2006). The coming of the Pakeha religion: The spiritual significance for Maori: A revisionist analysis of Maori 
spirituality and Pakeha religion. Auckland, New Zealand: Crystal Publishing.

Horkheimer, M. (1982). Critical theory. New York: Seabury Press.

Irwin, L. (2008). Coming down from above: Prophecy, resistance, and renewal in Native American religions. Norman, OK : University of Oklahoma Press.

Johnson, D. H. (1994). Nuer prophets: A history of prophecy from the Upper Nile in the nineteenth and twentieth centuries. Oxford, United Kingdom: Clarendon Press.

Johnson, D. H. \& Anderson, D. M. (1995). Revealing prophets. In D. M. Anderson \& D. H. Johnson, Revealing prophets (pp. 1-26). Athens, OH: Ohio University Press.

Johnston, A. M. (2006). Is the sacred for sale? Tourism and indigenous peoples. London, United Kingdom: Earthscan.

Ka'ai, T. (1995). Te tātari $i$ te kaupapa. Unpublished doctoral thesis, University of Waikato, Hamilton, New Zealand.

Ka'ai, T., \& Higgins, R. (2004). Te ao Māori - the Māori world-view. In T. Ka'ai, J. C. Moorfield, M. P. J. Reilly \& S. Mosley (Eds.), Ki te whaiao: An introduction to Mãori culture and society (pp. 13-25). Auckland, New Zealand: Pearson Education New Zealand.

Ka'ai, T. M., Moorfield, J. C., Reilly, M. P. J. \& Mosley, S. (Eds.). (2004). Ki te whaiao: an introduction to Mãori culture and society. Auckland, New Zealand: Pearson.

Ka'ai-Mahuta, R. (2010). He kupu tuku iho mō tēnei reanga: A critical analysis of waiata and haka as commentaries and archives of Māori political history. Unpublished doctoral thesis, Auckland University of Technology, Auckland, New Zealand.

Kovach, M. (2009). Indigenous methodologies: characteristics, conversations, and contexts. Toronto: University of Toronto Press.

Kreisel, H. (2001). Prophecy: The history of an idea in Medieval Jewish philosophy. Dordrecht, The Netherlands: Kluwer Academic Publishers.

Kunnie, J. E. \& Goduka, N. I. (Eds). (2006). Indigenous peoples' wisdom and power: Affirming our knowledge through narratives. Burlington, VT: Ashgate.

Lankshear, C. (1993). Functional literacy from a Freirean point of view. In P. McLaren \& P. Leonard (Eds.), Paulo Freire: A critical encounter (pp. 90-118). London, United Kingdom: Routledge.

Mataira, P. J. (2000). Mana and tapu: Sacred knowledge, sacred boundaries. In G. Harvey (Ed.), Indigenous religions: A companion (pp. 99-112). London \& New York: Cassell.

McCreanor, T. (2009, August). Challenging and countering anti-Maori discourse: Practices for decolonisation. Keynote speech presented at the New Zealand Psychological Society Conference, Palmerston North, New Zealand. Retrieved from: http://www.shore.ac.nz/projects/PsychologicalSocietyKeynote.pd $\mathrm{f}$

McLean, M. \& Orbell, M. (1975). Traditional songs of the Maori. Auckland, New Zealand: Auckland University Press. 
Nepe, T. (1991). E hao nei e tenei reanga: te toi huarewa tipuna; Kaupapa Māori, an educational intervention system. Unpublished master's thesis, The University of Auckland, Auckland, New Zealand.

Neylan, S. (2002). The heavens are changing: Nineteenth-century protestant missions and Tsimshian Christianity. Montreal, Quebec: McGill-Queen's University Press.

Nissinen, M. (2003). Prophets and prophecy in the ancient Near East. Leiden, The Netherlands: Brill.

Okigbo, C. (1996). Contextualising Freire in African sustainable development. Africa Media Review, 10(1), 31-53.

Paul, G. M. (1995). Te Houhi and Waiohau 1B. Te Runanganui o Te Ika Whenua - WAI 212.

Pere, R. T. (2006). A celebration of Maori sacred and spiritual wisdom. In J. E. Kunnie \&

N. I. Goduka (Eds.), Indigenous peoples' wisdom and power: Affirming our knowledge through narratives (pp. 143-157). Burlington, VT: Ashgate.

Pihama, L. (2001). Tìhei mauri ora honouring our voices: Mana wahine as a kaupapa Māori theoretical framework. Unpublished doctoral thesis, The University of Auckland, Auckland, New Zealand.

Pouwhare, R. M. I. (2004). Brief of evidence of Robert Marunui Iki Pouwhare dated the 14th day of March 2004. Wai 894/Wai 726. Submission to the Waitangi Tribunal, Wellington, New Zealand.

Rangihau, J. (1992). Being Maori. In M. King (Ed.), Te ao hurihuri: aspects of Maoritanga. Auckland: Reed. (needs page numbers)

Rangiwai, B. (2010). The effects of racism on Māori land loss: Colonising discourses for Te

Patuheuheu and Ngäti Haka (unpublished master's thesis). Te Whare Wānanga o Awanuiārangi, Whakatāne.

Rangiwai, B. (2011a). Te Umutaoroa, Patuheuheu and Ngāti Haka: Towards a prophetic model for unity and transformation. Te Kaharoa: The eJournal of Indigenous Pacific Issues, 4 (1), 1-32.

Rangiwai, B. (2011b). 'Race' and the politics of land loss: Colonising discourses for Patuheuheu and Ngāti Haka. Te Kaharoa: The eJournal of Indigenous Pacific Issues, 4(1), 40-96. Retrieved from http: / / tekaharoa.com/index.php/tekaharoa

Roberts, P. (2005). Pedagogy, politics and intellectual life: Freire in the age of the market. Policy Futures in Education,3(4), 446-458.

Robinson, S. T. (2005). Tohunga: The revival: Ancient knowledge for the modern era. Auckland, New Zealand: Reed Publishing.

Ross, W. Hugh. (1966). Te Kooti Rikirangi: General and prophet. Auckland: Collins.

Schipani, D. S. (1984). Conscientization and creativity: Paulo Freire and Christian education. Lanham, MD: University Press of America.

Seitz, C. R. (2007). Prophecy and hermeneutics: Toward a new introduction to the prophets. Grand Rapids, MI: Baker Academic. 
Smith, C. \& Ward, G. K. (Eds.). (2000). Indigenous cultures in an interconnected world. St Leonards, Australia: Allen \& Unwin.

Smith, L. T. (1997). Maori women: discourses, projects and mana wahine. In S. Middleton \& A. Jones (Eds.), Maori women and education 2 (pp. 33-51). Auckland: Auckland University Press \& Bridget Williams Books.

Smith, L. T. (1999). Decolonizing methodologies. Dunedin: Otago University Press.

Smoak, G. E. (2006). Ghost dances and identity: Prophetic religion and American Indian ethnogenesis in the nineteenth century. Berkeley \& Los Angeles, CA: University of California Press.

Trompf, G. (Ed.). (1977). Prophets of Melanesia. Port Moresby, Papua New Guinea \& Suva, Fiji: Institute of Papua New Guinea Studies $\&$ Institute of Pacific Studies, University of the South Pacific.

Wagstrom, T. (2005). Broken tongues and foreign hearts: The religious frontier in early nineteenth-century South Africa and New Zealand. In P. Brock (Ed.), Indigenous peoples and religious change (pp. 51-78). Leiden, The Netherlands: Brill.

Walker, R. (1990). Ka whawhai tonu matou: struggle without end. Auckland: Penguin Books.

Walker, R. (1996). Nga pepa a Ranginui. The Walker papers. Auckland: Penguin Books.

Walker, S. (1996). Kia tau te rangimarie: Kaupapa Maori theory as resistance against the construction of Maori as the other. Unpublished master's thesis. University of Auckland, Auckland, New Zealand.

Westermann, C. (1967). Basic forms of prophetic speech. Philadelphia: Westminster Press.

Whyte, R. (2011, September 23). Dance review: Te Houhi - the people and the land are one. New Zealand Herald. Retrieved January 20, 2012

from http://www.nzherald.co.nz/entertainment/news/article.cfm?c_id $=1501119 \&$ objectid $=10753801$

Wolfenstein, E. V. (1993). Psychoanalytic Marxism: Groundwork. London: Free Association Press.

Wouden, A. (1980). Te Houhi, the land, the people and the school. Historical review, Journal of the Whakatane and District Historical Society, 28(1), 2-16. 